\title{
EVALUASI KINERJA DIVISI TI PT.PGSN DALAM PENGELOLAAN DATA SESMIK
}

\author{
Mudjianto ${ }^{1}$, Heri Satria Setiawan ${ }^{2}$ \\ Program Studi Informatika, Universitas Indraprasta PGRI \\ Mudjianto_rachman@yahoo.com ${ }^{1}$, heri.satria71@yahoo.com ${ }^{2}$
}

\begin{abstract}
Abstrak
Sumber daya alam menjanjikan potensi pembangunan ekonomi yang luar biasa, yang harus dapat dimanfaatkan dengan seoptimal mungkin. Untuk mewujudkannya, salah satu faktor yang mempengaruhi keberhasilan bisnis suatu organisasi adalah pengelolaan infrastruktur teknologi informasi (TI) yang dijalankan dengan baik. Kualitas produk dan layanan SI/TI dapat diukur dari persepsi pelanggan internal. Beberapa perusahaan komputer sudah mulai bekerja sama dengan perusahaan Industri Perminyakan untuk membangun HPC Cluster guna membantu pemrosesan data explorasi sesmik supaya dapat diproses dengan cepat. HPC (High Performance Computing) merupakan teknologi yang memanfaatkan proses paralel komputer sebagai langkah untuk menyelesaikan pekerjaan yang membutuhkan performa komputasi yang besar. Pemrosesan data sesmik yang besar memerlukan kemampuan komputer yang cepat dan stabil. Tujuannya digunakan untuk melayani permintaan pelanggan internal / pengguna maupun external / pelanggan. Dengan dasar ini penulis mengadakan penelitian di PT.PGSN Jakarta Selatan. Penelitian ini terdiri dari dua jenis, yaitu penelitian korelasi yang akan menguji hubungan antara kepuasan pelanggan internal dengan tujuh variabel independen kualitas produk dan layanan SI/TI dan hubungan antara persepsi peningkatan kinerja pelanggan internal terhadap tujuh variabel independen kualitas produk dan layanan SI/TI. Ketujuh variabel tersebut adalah : availability, user friendliness, productivity, reliability, durability, responsiveness dan timeless of support. Serta penelitian komparasi untuk melihat ada/tidaknya perbedaan penilaian yang signifikan antara pelanggan internal dengan Sumber Daya Manusia IT dalam menilai aspek-aspek kinerja. Keenam aspek kinerja yang dianalisis yatu: tanggapan terhadap masalah, pemeliharaan Software, Hardware dan jaringan, pengembangan sistem informasi, pemeliharaan program \& SI, password dan kontrol daring. Uji korelasi dilakukan dengan menggunakan metode analisis korelasi Spearman, sedangkan uji komparasi dilakukan dengan menggunakan metode analisis Mann-whitney.
\end{abstract}

Kata Kunci : Kepuasan, Kinerja, Layanan

\begin{abstract}
Natural resources promise extraordinary economic development potential, which must be utilized as optimally as possible. To make it happen, one of the factors that influences the success of an organization's business is the well-managed management of information technology (IT) infrastructure. The quality of SI / IT products and services can be measured by internal customer perceptions. Several computer companies have begun to work with Petroleum Industry companies to build HPC Clusters to help process physical exploration data so that it can be processed quickly. HPC (High Performance Computing) is a technology that utilizes computer parallel processes as a step to complete work that requires large computing performance. Large processing of sesmik data requires fast and stable computer capabilities. The goal is to serve internal / user and external / customer requests. On this basis the author conducted a research at PT.PGSN South Jakarta. This study consists of two types, namely correlation research which will examine the relationship between internal customer satisfaction with seven independent variables of product / service quality of IS / IT and the relationship between perceptions of increasing internal customer performance on seven independent variables of product / service quality of IS / IT. The seven variables are: availability, user friendliness, productivity, reliability, durability, responsiveness and timeless of support. As well as comparative research to see whether there is a difference / significant difference between internal customers and IT Human Resources in assessing performance aspects. The six aspects of performance were analyzed: problem response, Software, Hardware and network maintenance, information system
\end{abstract}


development, program \& SI maintenance, passwords and online control. Correlation tests were carried out using the Spearman correlation analysis method, while the comparative test was carried out using the Mann-Whitney analysis method.

Key Words : Satisfaction, Performance, Services

\section{PENDAHULUAN}

Perkembangan teknologi SI / IT beberapa tahun ini terakhir ini sangat pesat sehingga membantu kalangan bisnis .Ketika keberhasilan bisnis tergantung pada infrastruktur Teknologi Informasi (TI) yang dijalankan dengan baik, maka kemampuan Divisi TI dalam suatu perusahaan untuk mengelola layanan TI harus menjadi prioritas utama. Derajat kualitas produk dan layanan SI/TI dapat diukur dari kepuasan pengguna terhadap produk dan layanan SI/TI tersebut. Semakin tinggi kualitas suatu produk dan layanan SI/TI yang diberikan oleh Divisi TI maka akan semakin besar pula kontribusi divisi TI terhadap kesuksesan perusahaan. PT.PGSN. Dengan melibatkan beberapa komponen yaitu Opensource Linux sebagai sistem operasi, perangkat keras berupa PC Cluster, Cube Manager sebagai basis datanya dan pengguna aplikasi (internal user) atau pelanggan ( External/Client ), maka dapat kita cari sebab dan akibat dari pengguna internal atau user. Dalam salah satu hubungan sebab-akibat pada IT Balanced Scorecard yang dikembangkan oleh Gremberger dinyatakan bahwa bila produk dan layanan TI yang berkualitas terpenuhi, maka pengguna akan puas, sehingga dapat dikatakan bahwa divisi TI telah memberikan kontribusi yang positif untuk perusahaan atau organisasi.
A. Konsep IT Balanced Scorecard

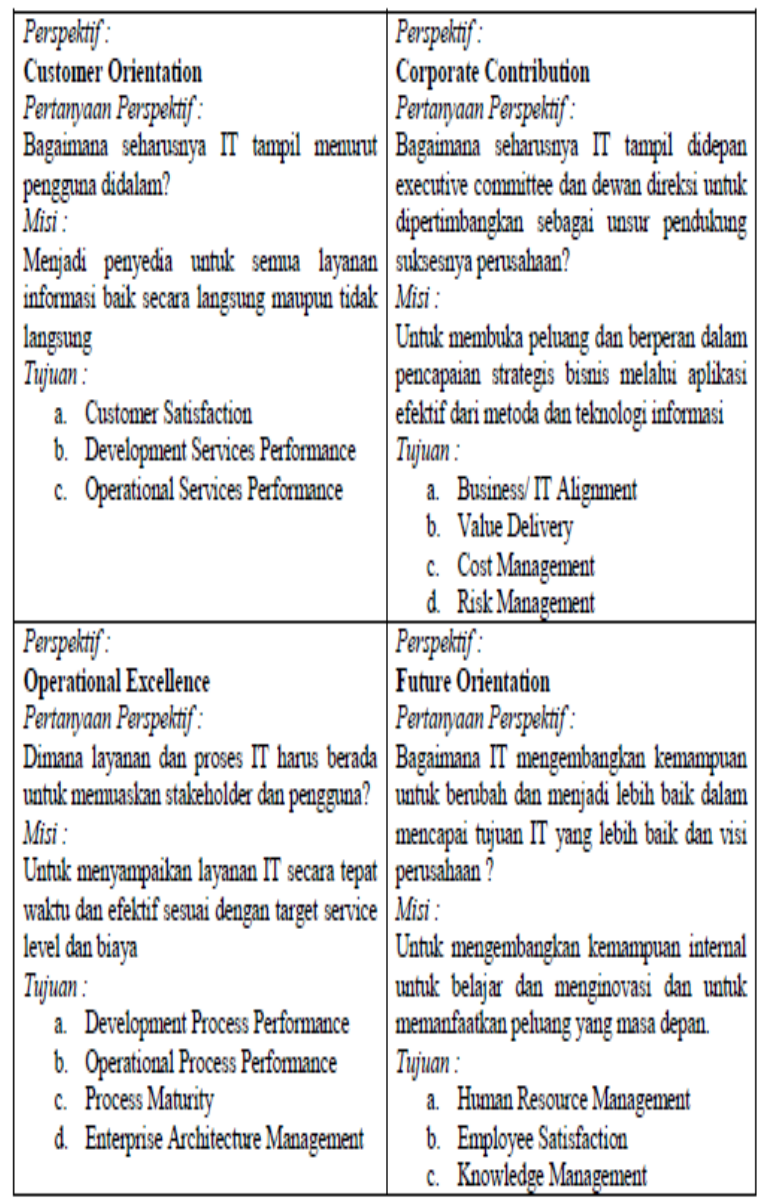

\section{Gambar 1. Standard IT Balanced Scorecard}

Komponen-komponen yang penting dari sebuah IT BSC adalah hubungan sebabakibat diantara tolok ukur. Hubungan hubungan ini dinyatakan melalui dua jenis tolok ukur kunci yaitu: tolok ukur keluaran (outcome measure) yang dapat diukur secara fisik serta tolok ukur pendorong performa (performance drivers) yang merupakan faktor-faktor yang mendorong kinerja pada masa yang akan datang. 
Gambar berikut menjelaskan keterkaitan antara keempat perspektif pada IT BSC.

\section{JIKA}

Keahlian karyawan TI meningkat (orientasi masa depan) MAKA

ini dapat menghasilkan kualitas yang lebih baik dari sistem yang dikembangkan KEMUDIAN

ini dapat memenuhi harapan pengguna yang lebih baik (orientasi pengguna)

KEMUDIAN

ini dapat meningkatkan dukungan proses bisnis

(kontribusi bisnis)

\section{Gambar 2. Hubungan Sebab- Akibat}

B. Hipotesis Penelitian

Karena penelitian ini bertujuan untuk melihat pengaruh kinerja divisi TI terhadap kepuasan pelanggan serta untuk membandingkan persepsi penilaian kinerja antara divisi TI dengan pelanggan internal maka ada tiga hipotesis kerja yang telah dirumuskan, yaitu

Hipotesis untuk pengujian korelasi

Hipotesis 1 : Hubungan antara kinerja divisi TI yang ditinjau dari kualitas produk dan layanan SI/TI yang dihasilkannya terhadap kepuasan pelanggan internal

HO : Kinerja Divisi TI tidak berpengaruh positif terhadap kepuasan pelanggan internal.

H1 : Kinerja Divisi TI berpengaruh positif terhadap kepuasan pelanggan internal.

Hipotesis 2 : Hubungan antara kinerja divisi TI yang ditinjau dari kualitas produk dan layanan SI/TI yang dihasilkannya terhadap persepsi peningkatan kinerja pelanggan internal

HO : Kinerja Divisi TI tidak berpengaruh positif terhadap persepsi peningkatan kinerja pelanggan internal. H1 : Kinerja Divisi TI berpengaruh positif terhadap persepsi peningkatan kinerja pelanggan internal.
Hipotesis untuk pengujian komparasi

Hipotesis 3 : Perbedaan persepsi antara pelanggan internal dan personel divisi TI dalam menilai kinerja divisi TI secara keseluruhan

H0 : Tidak ada perbedaan persepsi antara pelanggan internal dan personel divisi TI dalam menilai kinerja divisi TI secara keseluruhan.

H1 : Ada perbedaan persepsi antara pelanggan internal dan personel divisi TI dalam menilai kinerja divisi TI secara keseluruhan

\section{METODE PENELITIAN}

Penelitian dilakukan di PT.PGSN, suatu perusahaan yang bergerak di bidang eksplorasi gas dan minyak bumi. Penelitian melibatkan divisi TI dimana dinilai kinerjanya, apakah sesuai dengan tujuan perusahan atau tidak. Data diambil dengan melakukan wawancara dan observasi dilapangan, diolah dengan menggunakan SPSS sehingga diperoleh hasil yang menunjukan kinerja divisi TI PT.PGSN.

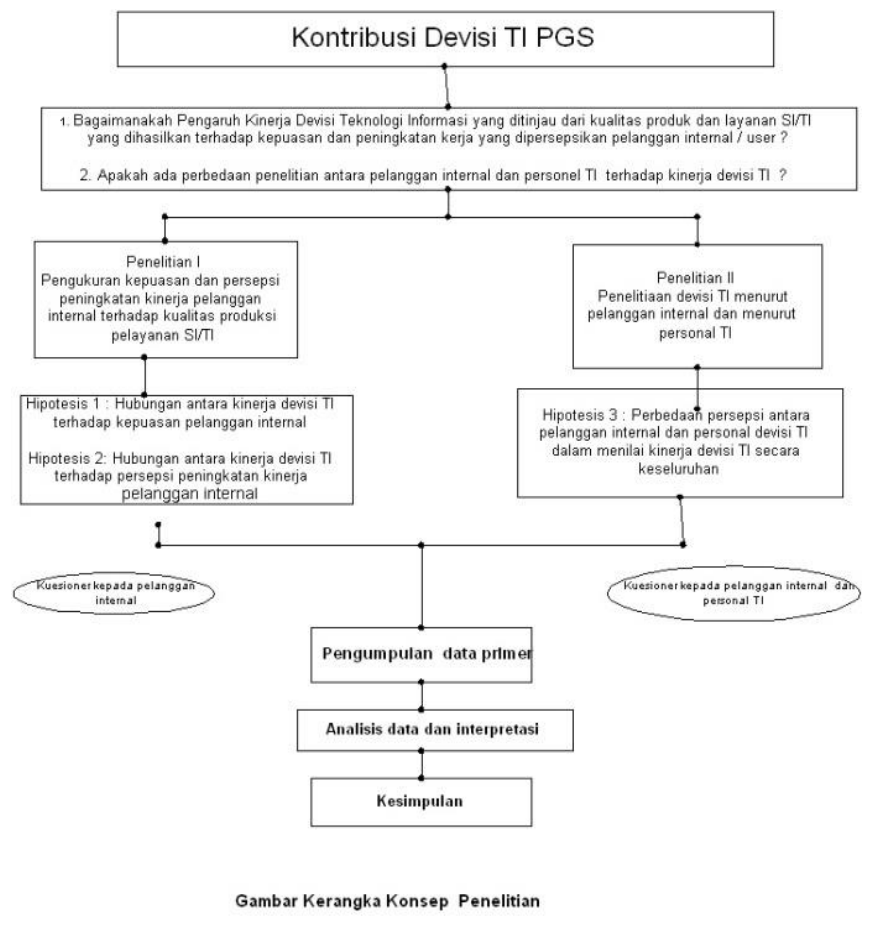

Gambar 3. Kerangka Konsep Penelitian pada divisi IT PT.PGSN 
Penelitian ini terdiri dari dua jenis penelitian yaitu korelasi yang akan menguji hipotesis 1 dan hipotesis 2 serta penelitian komparasi yang akan menguji hipotesis 3.

Metode dari penelitian ini adalah metode survey. Data yang digunakan adalah data kuantitatif.Data didapatkan dari pendapat mereka tentang pernyataan yang diajukan dalam kuesioner.

\section{HASIL DAN PEMBAHASAN}

Analisis merupakan tindakan mengolah data menjadi informasi yang bermanfaat untuk masalah riset dan selanjutnya akan dilakukan interpretasi dari hasil keluaran atau output analisis tersebut agar mudah dipahami.

\section{Pengelompokan Data}

Setelah dilaksanakan serangkaian penelitian di PT. PGSN, penulis memperoleh sejumlah data yang dianggap cukup untuk menjelaskan hasil temuan penulisan ini, serta menguji hipotesa yang telah disebutkan. Penyebaran kuesioner kepada responden pada tiap bagian kerja dilakukan dengan memberikan langsung kepada responden di tiap-tiap bagian kerja.

\section{Hasil Penelitian Korelasi}

Hasil analisis dan penelitian korelasi yang akan diuraikan meliputi hasil analisis validitas dan reliabilitas dan kuesioner, hasil analisis statistik deskriptif jawaban responden serta hasil analisis korelasi Spearman.

\section{Analisis Validitas dan Reliabilitas \\ 1 Pengujian Validitas}

Uji validitas kuesioner dilakukan dengan cara mengkorelasikan nilai butir-butir pernyataan tiap variabel dengan nilai totalnya, dan pengujian validitas diperoleh 34 butir pernyataan yang valid dan total 37 butir pernyataan. Hasilnya dapat dilihat pada tabel berikut ini :
Tabel 1. Validitas Butir Pernyataan

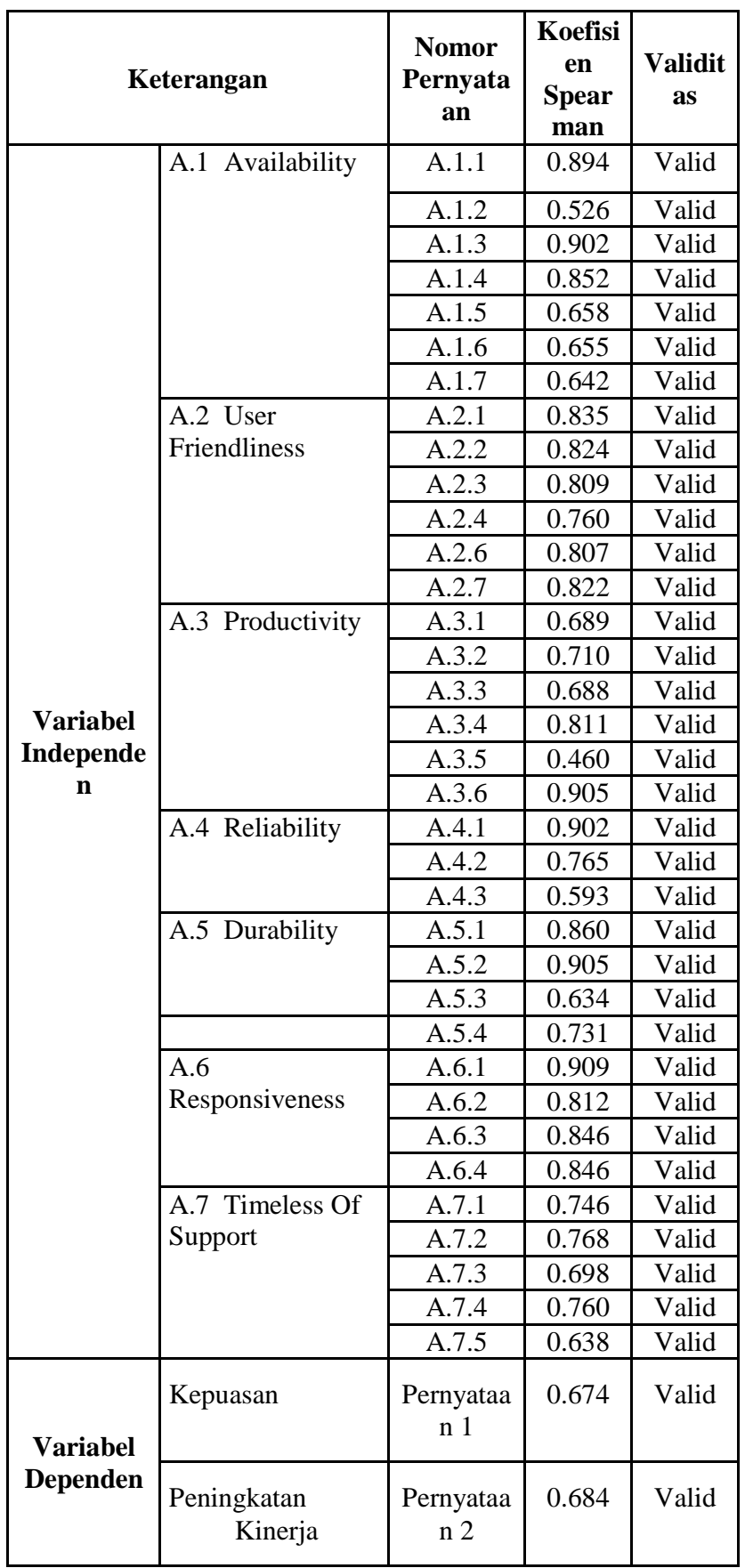

\section{Pengujian Reliabilitas}

Hasil dan reliabilitas menunjukan bahwa nilai alpha untuk masing-masing butir pernyataan adalah $>0,5$ dengan nilai alpha untuk keseluruhan pernyataan adalah 0,746 . seperti yang terlihat pada tabel 2 Reliabilitas Butir Pernyataan. Ini berarti 
bahwa semua pernyataan yang valid tersebut adalah reliabel.

Tabel 2. Reliabilitas Butir Pernyataan

\begin{tabular}{|l|c|c|}
\hline \multicolumn{1}{|c|}{ Keterangan } & $\begin{array}{c}\text { Alpha } \\
\text { Cronbach }\end{array}$ & $\begin{array}{c}\text { Reliability } \\
\text { (r-alpha } \geq\end{array}$ \\
\hline Availability (A.1.1) & 0.828 & Reliabel \\
A.1.2 & 0.857 & Reliabel \\
A.1.3 & 0.792 & Reliabel \\
A.1.4 & 0.802 & Reliabel \\
A.1.5 & 0.829 & Reliabel \\
A.1.6 & 0.832 & Reliabel \\
A.1.7 & 0.839 & Reliabel \\
User Friendliness & 0.903 & Reliabel \\
(A.2.1) & & \\
A.2.2 & 0.922 & Reliabel \\
A.2.3 & 0.900 & Reliabel \\
A.2.4 & 0.909 & Reliabel \\
A.2.6 & 0.920 & Reliabel \\
A.2.7 & 0.915 & Reliabel \\
Productivity (A.3.1) & 0.834 & Reliabel \\
A.3.2 & 0.854 & Reliabel \\
A.3.3 & 0.828 & Reliahel \\
A.3.4 & 0.797 & Reliabel \\
A.3.5 & 0.875 & Reliabel \\
A.3.6 & 0.806 & Reliabel \\
Reliability (A.4.3) & 0.222 & Reliabel \\
A.4.4 & 0.481 & Reliabel \\
A.4.5 & 0.891 & Reliabel \\
Durability (A.5.1) & 0.679 & Reliahel \\
A.5.2 & 0.664 & Reliabel \\
A.5.3 & 0.809 & Reliabel \\
A.5.4 & 0.854 & Reliabel \\
Responsiveness & 0.872 & Reliabel \\
(A.6.1) & & \\
A.6.2 & 0.919 & Reliabel \\
A.6.3 & 0.830 & Reliabel \\
A.6.4 & 0.860 & Reliahel \\
Timeless Of Support & 0.805 & Reliabel \\
(A.7.1) & & \\
A.7.2 & 0.774 & Reliabel \\
A.7.3 & 0.763 & Reliabel \\
A.7.4 & & Reliabel \\
A.7.5 & Reliabel \\
Kepuasan (Pernyataan & \\
1) & 0.886 & Reliabel \\
Peningkatan kinerja \\
(Pernyataan 2) & & Reliabel \\
\hline & & \\
\hline & & \\
\hline
\end{tabular}

Catatan : $\mathrm{n}($ sampel $)=20$

Reliabilitas keseluruhan : 0,475

\section{Hasil Analisis Statistik Deskriptif}

Analisis deskriptif dilakukan untuk memberikan gambaran mengenai data lamanya masa kerja responden, sistem aplikasi yang digunakan oleh responden dan fungsi kerja responden. Dan 20 orang responden yang secara lengkap telah mengisi kuesioner terdiri dari : 14 staff sebagai pelanggan internal dan 6 staff sebagai divisi TI .

Untuk sebaran responden berdasarkan lamanya masa kerja diperoleh bahwa sebanyak 3 orang memiliki masa kerja kurang dari1 tahun, jumlah responden yang memiliki masa kerja selama 1-2 tahun adalah sebanyak 3 orang, 3-4 tahun sebanyak 3 orang, 5-7 tahun sebanyak 4 orang, 7-8 tahun sebanyak 4 orang dan yang memiliki masa kerja lebih dari 8 tahun adalah sebanyak 2 orang. Persentase sebaran responden dapat dilihat pada gambar 1.

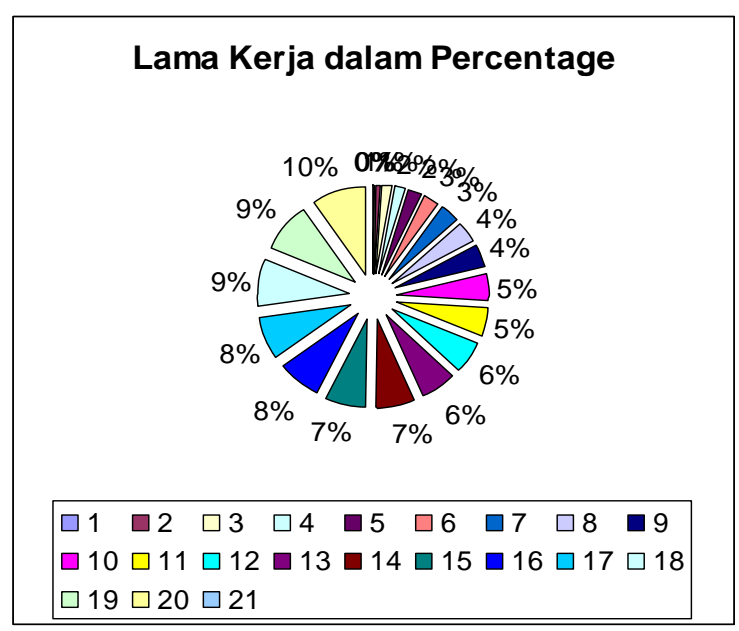

Gambar 4. Persentase Lama Kerja

Sebaran data variabel independent kinerja divisi TI yang terdiri dari tujuh variabel kualitas produk dan layanan SI/TI yang diperoleh dari kuesioner menunjukan bahwa untuk skala 1 sampai $5(1=$ STS atau sangat rendah, $2=$ TS atau rendah, $3=$ $\mathrm{N}$ atau sedang, $4=\mathrm{S}$ atau tinggi, $5 \mathrm{SS}$ atau sangat tinggi) nilai rata-rata yang dihasilkan untuk keenam vaniabel Availability, UserFriendly, productivity, reliability, responsiveness dan timeless of support berada pada posisi sedang/cukup. Nilai rata-rata untuk keseluruhan variabel 
independent (yang menggambarkan tingkat kualitas produk dan layanan SI/TI secara keseluruhan) menurut persepsi pelanggan internal adalah sebesar 4.01 atau berada pada posisi sedang/cukup. Nilai rata-rata variabel kualitas hampir mendekati sama ,tidak ada variabel yang menonjol rendah. Ringkasan data-data tersebut dapat dilihat pada tabel 3 .

\section{Tabel 3. Deskriptif Variabel Independent}

\begin{tabular}{|l|r|r|r|r|r|}
\hline & $\begin{array}{c}\text { Jumlah } \\
\text { Sampel }\end{array}$ & $\begin{array}{c}\text { Nilai } \\
\text { Minimum }\end{array}$ & $\begin{array}{c}\text { Nilai } \\
\text { Maximum }\end{array}$ & $\begin{array}{c}\text { Nilai } \\
\text { rata- } \\
\text { rata }\end{array}$ & $\begin{array}{c}\text { Deviasi } \\
\text { standar }\end{array}$ \\
\hline Availability & 20 & 4 & 6 & 4.8 & 0.558 \\
User & 20 & 2 & 5 & 3.7 & 0.620 \\
Friendliness & & & & & \\
Productivity & 20 & 2 & 5 & 3.8 & 0.620 \\
Reliability & 20 & 3 & 5 & 3.7 & 0.513 \\
Durability & 20 & 3 & 5 & 3.8 & 0.594 \\
Responsiveness & 20 & 3 & 5 & 4.25 & 0.480 \\
Timeless Of & 20 & 3 & 5 & 4.05 & 0.472 \\
Support & & & & 4.01 & \\
\hline Rata- rata & & & & & \\
Keseluruhan & & & & & \\
\hline
\end{tabular}

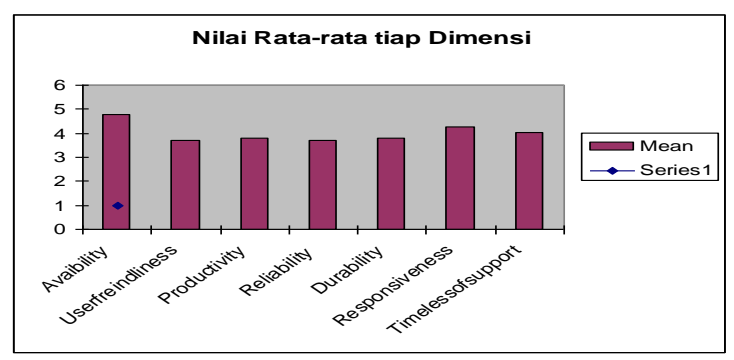

\section{Gambar 5. Nilai Rata-Rata Untuk Tiap Dimensi}

Sedangkan ringkasan deskriptif untuk variabel dependent kepuasan dan peningkatan kinerja pelanggan internal dapat dilihat pada tabel 4 Deskriptif variabel dependent.
Tabel 4. Deskriptif Variabel Dependent

\begin{tabular}{|l|r|r|r|r|r|}
\hline & $\begin{array}{l}\text { Jumla } \\
\mathrm{h} \\
\text { Sampe } \\
\mathrm{l}\end{array}$ & $\begin{array}{l}\text { Nilai } \\
\text { Minimu } \\
\mathrm{m}\end{array}$ & $\begin{array}{c}\text { Nilai } \\
\text { Maximu } \\
\mathrm{m}\end{array}$ & $\begin{array}{r}\text { Nilai } \\
\text { rata- } \\
\text { rata }\end{array}$ & $\begin{array}{l}\text { Deviasi } \\
\text { standar }\end{array}$ \\
\hline $\begin{array}{l}\text { Kepuasan ( Y1 ) } \\
\text { pelanggan } \\
\begin{array}{l}\text { Kinerja ( Y2 ) } \\
\text { pelanggan }\end{array}\end{array}$ & 20 & 3.720 & 4.25 & 3.97 & 0,858 \\
\hline Rata-rata keseluruhan & & 2.00 & 5.00 & 3.95 & 0.759 \\
\hline
\end{tabular}

Dari tabel 4 terlihat bahwa tingkat kepuasan pelanggan internal terhadap kualitas produk dan layanan SI/TI saat ini berada pada posisi netral atau sedang dengan nilai rata-rata sebesar 3.97 dan nilai rata-rata variabel kinerja pelanggan internal adalah sebesar 3.95 yang berarti berada pada posisi netral atau sedang. Sehingga nilai rata-rata terhadap keseluruhan variabel dependent adalah sebesar 3.96 yang berarti berada pada posisi sedang.

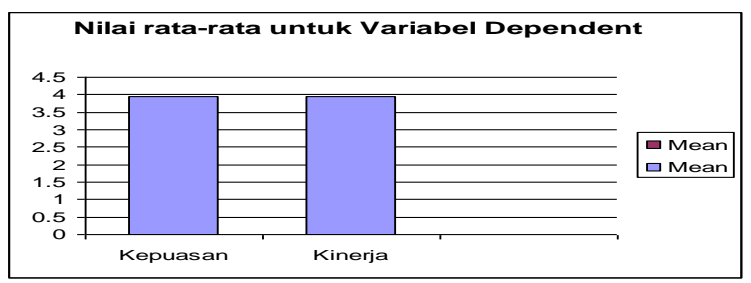

Gambar 6. Nilai Rata-Rata Untuk Variabel Dependent

\section{Hasil Analisis Korelasi Spearman}

Hasil analisis koefisien korelasi spearman yang menggunakan siginfikansi dua sisi (Sig.(2-tailed)) dapat dilihat pada tabel 5. Hasil Analisis Korelasi Spearman Variabel Independent terhadap variabel Dependent. Nilai koefisien seluruh variabel kualitas produk dan layanan SI/TI yang terdiri dan tujuh variabel yaitu : Availability, User friendliness, productivity, reliability, durability, responsivenss dan timeless of support terhadap variabel kepuasan pelanggan dan terhadap peningkatan 
kinerja pelanggan internal adalah $<0.025$ ( $0.05: 2=0,025$ ), kecuali Avaibility . Tanda bintang dua $(* *)$ menunjukan korelasi antara kedua variabel adalah sangat kuat, sedangkan tanda bintang satu (*) menunjukan korelasi yang lemah antara kedua variabel.

Tabel 5. Hasil Analisis Korelasi Spearmnn Variabel Independent Terhadap Variabel Dependent

\begin{tabular}{|c|c|c|c|c|c|}
\hline \multirow[b]{2}{*}{$\begin{array}{l}\mathrm{N} \\
\mathrm{o}\end{array}$} & \multirow[b]{2}{*}{$\begin{array}{l}\text { Independen } \\
\text { variabel }\end{array}$} & \multicolumn{2}{|c|}{$\begin{array}{l}\text { Koefisien Korelasi } \\
\text { Spearman }\end{array}$} & \multicolumn{2}{|c|}{$\begin{array}{l}\text { Koefisien } \\
\text { Signifikansi }\end{array}$} \\
\hline & & $\begin{array}{c}\text { Kepuas } \\
\text { an } \\
\text { Pelang } \\
\text { gan } \\
\left(\mathrm{Y}_{1}\right)\end{array}$ & $\begin{array}{c}\text { Peningka } \\
\tan \\
\text { Kinerja } \\
\left(\mathrm{Y}_{2}\right)\end{array}$ & $\begin{array}{c}\text { Kepuas } \\
\text { an } \\
\text { Pelang } \\
\text { gan } \\
\left(Y_{1}\right)\end{array}$ & $\begin{array}{c}\text { Peningka } \\
\tan \\
\text { Kinerja } \\
\left(\mathrm{Y}_{2}\right)\end{array}$ \\
\hline 1 & Availability & 0.357 & 0.347 & 0.123 & 0.134 \\
\hline 2 & $\begin{array}{l}\text { User } \\
\text { Friendlines } \\
s\end{array}$ & $\begin{array}{r}0.652 * \\
*\end{array}$ & $0.658 * *$ & 0.002 & 0.002 \\
\hline 3 & $\begin{array}{l}\text { Productivit } \\
y\end{array}$ & $\begin{array}{r}0.794 * \\
*\end{array}$ & $0.771 * *$ & 0.000 & 0.000 \\
\hline 4 & Reliability & $\begin{array}{r}0.672 * \\
*\end{array}$ & $0.653^{*}$ & 0.001 & 0.002 \\
\hline 5 & Durability & $\begin{array}{r}0.757 * \\
*\end{array}$ & $0.780 * *$ & 0.000 & 0.000 \\
\hline 6 & $\begin{array}{l}\text { Responsive } \\
\text { ness }\end{array}$ & $\begin{array}{r}0.584 * \\
*\end{array}$ & $0.620 * *$ & 0.007 & 0.004 \\
\hline 7 & $\begin{array}{l}\text { Timeless Of } \\
\text { Support }\end{array}$ & $\begin{array}{r}0.674 * \\
*\end{array}$ & $0.684 * *$ & 0.001 & 0.001 \\
\hline
\end{tabular}

\section{Hasil Penelitian Komparasi}

Pada hasil penelitian komparasi akan diuraikan hasil analisis statistik deskriptif jawaban dan kedua kelompok responden yaitu kelompok pelanggan internal dan kelompok personel divisi TI serta hasil analisis mann-whitney.

\section{Analisis Statistik Deskriptif}

Untuk melakukan uji komparasi, sebanyak 6 orang personel TI dimintai pendapatnya untuk menilai kinerja divisi TI. Sedangkan jumlah pelanggan internal yang dimintai pendapatnya untuk menilai kinerja divisi TI adalah sebanyak 14 orang. Pengujian komparasi dengan menggunakan metode analisis mann-whitney membolehkan jumlah responden yang tidak seragam dan kedua sampel yang akan diuji.

Statistik deskriptif dan jawaban responden dapat dilihat pada tabel 6. Responden menilai bahwa aspek-aspek kinerja; Pemeliharaan S/W,H/W dan Jaringan , password, pemeliharaan program \& SI, pengembangan sistem informasi dan virus berada pada possi sedang dengan range nilai dan 3.74 - 3.93. Sedangkan untuk tanggapan masalah dinilai tinggi oleh responden dengan nilai rata-rata nya 4,70. Nilai rata-rata untuk kinerja divisi TI secara keseluruhan adalah 4.02 atau berada pada posisi baik.

\section{Tabel 6. Deskriptif Jawaban Pelanggan Internal}

\begin{tabular}{|c|c|c|c|c|c|}
\hline $\begin{array}{c}\text { Aspek } \\
\text { Kinerja yang } \\
\text { dinilai }\end{array}$ & $\mathrm{N}$ & $\underset{\mathrm{m}}{\operatorname{Minimu}}$ & $\begin{array}{c}\text { Maximu } \\
\mathrm{m}\end{array}$ & $\begin{array}{c}\text { Mea } \\
\mathrm{n}\end{array}$ & $\begin{array}{c}\text { Std. } \\
\text { Deviatio } \\
n\end{array}$ \\
\hline $\begin{array}{l}\text { Tanggapan } \\
\text { Terhadap } \\
\text { masalah }\end{array}$ & $\begin{array}{l}1 \\
4\end{array}$ & 4.00 & 5.00 & 4.07 & 0.432 \\
\hline $\begin{array}{l}\text { Pemeliharaan } \\
\text { S/W, H/W } \\
\text { dan jaringan }\end{array}$ & $\begin{array}{l}1 \\
4\end{array}$ & 4.00 & 5.00 & 3.93 & 0.385 \\
\hline $\begin{array}{l}\text { Pengembanga } \\
\mathrm{n} \text { SI }\end{array}$ & $\begin{array}{l}1 \\
4\end{array}$ & 3.00 & 5.00 & 3.74 & 0.526 \\
\hline $\begin{array}{l}\text { Pemeliharaan } \\
\text { Program \& SI }\end{array}$ & $\begin{array}{l}1 \\
4\end{array}$ & 3.00 & 5.00 & 3.79 & 0.674 \\
\hline $\begin{array}{l}\text { Password dan } \\
\text { control online }\end{array}$ & $\begin{array}{l}1 \\
4\end{array}$ & 3.00 & 5.00 & 3.90 & 0.646 \\
\hline Virus & $\begin{array}{l}1 \\
4\end{array}$ & 3.00 & 5.00 & 3.79 & 0.674 \\
\hline $\begin{array}{l}\text { Kinerja } \\
\text { Div.T1 } \\
\text { keseluruhan }\end{array}$ & $\begin{array}{l}1 \\
4\end{array}$ & 3.00 & 5.00 & 4.02 & 0.647 \\
\hline
\end{tabular}

Hasil jejak pendapat dengan 6 orang personel TI mengungkapkan penilaian kinerja divisi TI secara keseluruhan menurut persepsi pensonel TI berada pada posisi baik dengan nilai rata-rata sebesar 4.02 Keempat aspek kinerja yang juga berada pada posisi baik dengan range nilai 3.666-3.916 adalah pemeliharan S/W, H/W dan jaringan, pengembangan SI 
,pengembangan SI ,pemeliharaan program SI dan password dan control online. Sedangkan Virus pada posisi kurang dengan nilai 2.583 .

\section{Tabel 7. Deskiptif Jawaban Personel TI}

\begin{tabular}{|l|c|c|c|c|c|}
\hline $\begin{array}{l}\text { Aspek } \\
\text { Kinerja yang } \\
\text { dinilai }\end{array}$ & $\mathrm{N}$ & $\begin{array}{c}\text { Minimu } \\
\mathrm{m}\end{array}$ & $\begin{array}{c}\text { Maximu } \\
\mathrm{m}\end{array}$ & $\begin{array}{c}\text { Mea } \\
\mathrm{n}\end{array}$ & $\begin{array}{c}\text { Std. } \\
\text { Deviatio } \\
\mathrm{n}\end{array}$ \\
\hline $\begin{array}{l}\text { Tanggapan } \\
\text { Terhadap } \\
\text { masalah } \\
\text { Pemeliharaan }\end{array}$ & 6 & 3.50 & 5.00 & $\begin{array}{c}4.16 \\
6\end{array}$ & 0.683 \\
$\begin{array}{l}\text { S/W, H/W } \\
\text { dan jaringan }\end{array}$ & 3.00 & 4.50 & $\begin{array}{c}3.91 \\
6\end{array}$ & 0.664 \\
$\begin{array}{l}\text { Pengembanga } \\
\text { n SI }\end{array}$ & 6 & 3.33 & 4.00 & $\begin{array}{c}3.66 \\
6\end{array}$ & 0.299 \\
$\begin{array}{l}\text { Pemeliharaan } \\
\text { Program \& SI } \\
\text { Password dan } \\
\text { control online }\end{array}$ & 6 & 3.33 & 4.00 & $\begin{array}{c}3.88 \\
8\end{array}$ & 0.273 \\
$\begin{array}{l}\text { Virus } \\
\text { Kinerja Divisi }\end{array}$ & 6 & 4.00 & 5.00 & $\begin{array}{c}3.77 \\
8\end{array}$ & 0.272 \\
$\begin{array}{l}\text { TI } \\
\text { keseluruhan }\end{array}$ & 6 & 4.00 & 4.00 & $\mathbf{2 . 5 8}$ & 1.020 \\
$\mathbf{3}$ & 0.418 \\
\hline
\end{tabular}

\section{Hasil Analisis Mann Whitney}

Untuk menguji hipotesis dalam penelitian komparasi digunakan uji Mann-Whitney dengan pengambilan keputusan berdasarkan nilai Sig.(2-tailed). Hasil analisisnya telah diringkaskan dalam tabel 8 Koefisien Signifikansi aspek-aspek kinerja.

Tabel 8. Koefisien Signifikansi Aspekaspek Kinerja

\begin{tabular}{|l|r|r|r|r|r|r|r|}
\hline & $\begin{array}{r}\text { Tan } \\
\text { ggap }\end{array}$ & $\begin{array}{r}\text { Pass } \\
\text { wor } \\
\text { d }\end{array}$ & $\begin{array}{r}\text { Pro } \\
\text { g \& } \\
\text { SI }\end{array}$ & $\begin{array}{r}\text { Pe } \\
\text { ng. } \\
\text { SI }\end{array}$ & $\begin{array}{c}\text { H/W } \\
\text { \& }\end{array}$ & $\begin{array}{c}\text { Vir } \\
\text { Jan } \\
\text { gan }\end{array}$ & $\begin{array}{r}\text { Kin. } \\
\text { Tota } \\
1\end{array}$ \\
\hline Man & 42.0 & 0.00 & 42.0 & 40. & 35.5 & 33. & 0.00 \\
n- & 00 & 0 & 00 & 00 & 00 & 00 & 0 \\
Whit & & & & 0 & & 0 & \\
ney & & & & & & & \\
U & & & & & & & \\
Wilc & 63.0 & 105. & 63.0 & 61. & 56.5 & 54. & 105. \\
oxon & 00 & 000 & 00 & 00 & 00 & 00 & 000 \\
W & & & & 0 & & 0 & \\
Z & 0.00 & - & .000 & - & - & - & - \\
& 0 & 3.64 & & .16 & 0.55 & 0.7 & 3.64 \\
& & 7 & & 9 & 3 & 53 & 8
\end{tabular}

\begin{tabular}{|l|r|r|r|r|r|r|r|} 
Asy & 1.00 & 0.00 & 1.00 & 0.8 & 0.58 & .45 & 0.00 \\
mp. & 0 & 0 & 0 & 66 & 1 & 1 & 0 \\
Sig. & & & & & & & \\
$(2-$ & & & & & & & \\
taile & & & & & & & \\
d) & & & & & & & \\
Exac & 1.00 & 0.00 & 1.00 & 0.9 & 0.60 & .49 & 0.00 \\
t & $0(a)$ & $0(a)$ & $0(a)$ & $4(a$ & $2(a)$ & $4(a$ & $0(a)$ \\
Sig. & & & & ) & & ) & \\
{$\left[2^{*}\right.$} & & & & & & & \\
$(1-$ & & & & & & & \\
taile & & & & & & & \\
d & & & & & & & \\
Sig)] & & & & & & \\
\hline
\end{tabular}

a Not corrected for ties

b Grouping Variable: kelompokSampel

Dari table 8 terlihat bahwa nilai Asymp.Sig.(2-tailed) untuk kelima aspek kinerja adalah lebih besar dari 0,05. Aspek-aspek. itu adalah Tanggapan terhadap masalah, Program dan Sistem informasi , Pengembangan SI, S/W H/W dan jaringan dan virus. Sedangkan untuk password mempunyai nilai lebih kecil dari 0.05 . Nilai Asymp. Sig.(2-tailed) untuk penilaian kinerja secara keseluruhan adalah 0,00. Tabel 9 menyajikan ringkasan hasil pengujian perbedaan persepsi penilaian kinerja dari dua kelompok responden.

\section{Tabel 9. Summary Perbedaan Persepsi} Penilaian Kinerja Divisi TI

\begin{tabular}{|c|c|c|c|c|c|}
\hline $\begin{array}{l}\text { Aspek Kinerja } \\
\text { yang Dinilai }\end{array}$ & $\begin{array}{c}\text { Kelompok } \\
\text { Sampel }\end{array}$ & $\mathrm{N}$ & Mean & Signifikansi & Keterangan \\
\hline \multirow{2}{*}{$\begin{array}{l}\text { Tanggapan } \\
\text { terhadap } \\
\text { masalah }\end{array}$} & $\begin{array}{l}\text { Pelanggan } \\
\text { Internal }\end{array}$ & 14 & 4.07 & \multirow{2}{*}{1.000} & Beda tidak \\
\hline & $\begin{array}{l}\text { Personel } \\
\text { TI }\end{array}$ & 6 & 4.166 & & Signifikan \\
\hline \multirow{2}{*}{$\begin{array}{l}\text { Pemeliharaan } \\
\text { S/W, H/W dan } \\
\text { jaringan }\end{array}$} & $\begin{array}{l}\text { Pelanggan } \\
\text { Internal }\end{array}$ & 14 & 3.93 & \multirow{2}{*}{0.581} & Beda tidak \\
\hline & $\begin{array}{l}\text { Personel } \\
\text { TI }\end{array}$ & 6 & 3.916 & & Signifikan \\
\hline \multirow{2}{*}{$\begin{array}{l}\text { Pengembangan } \\
\text { SI }\end{array}$} & $\begin{array}{l}\text { Pelanggan } \\
\text { Internal }\end{array}$ & 14 & 3.74 & \multirow{2}{*}{0.866} & Beda tidak \\
\hline & $\begin{array}{r}\text { Personel } \\
\text { TI }\end{array}$ & 6 & 3.666 & & Signifikan \\
\hline \multirow{2}{*}{$\begin{array}{l}\text { Pemeliharaan } \\
\text { Program \& SI }\end{array}$} & $\begin{array}{l}\text { Pelanggan } \\
\text { Internal }\end{array}$ & 14 & 3.79 & \multirow{2}{*}{1.000} & \\
\hline & $\begin{array}{l}\text { Personel } \\
\text { TI }\end{array}$ & 6 & 3.888 & & Signifikan \\
\hline
\end{tabular}




\begin{tabular}{|l|l|c|c|c|c|}
\hline $\begin{array}{l}\text { Password dan } \\
\text { control online } \\
\text { lainnya }\end{array}$ & $\begin{array}{l}\text { Pelanggan } \\
\text { Internal }\end{array}$ & 14 & 3.90 & & Beda \\
\cline { 2 - 4 } & $\begin{array}{l}\text { Personel } \\
\text { TI }\end{array}$ & 6 & 3.778 & 0.000 & Signifikan \\
\hline \multirow{2}{*}{ Virus } & $\begin{array}{l}\text { Pelanggan } \\
\text { Internal }\end{array}$ & 14 & 3.79 & & Beda \\
\cline { 2 - 4 } & $\begin{array}{l}\text { Personel } \\
\text { TI }\end{array}$ & 6 & 2.583 & 0.451 & Signifikan \\
\hline \multirow{2}{*}{$\begin{array}{l}\text { Kinerja Div.TI } \\
\text { keseluruhan }\end{array}$} & $\begin{array}{l}\text { Pelanggan } \\
\text { Internal }\end{array}$ & 14 & 4.02 & & Beda tidak \\
\cline { 2 - 4 } & $\begin{array}{l}\text { Personel } \\
\text { TI }\end{array}$ & 6 & 4.250 & 0.000 & signifikan \\
\hline
\end{tabular}

Dari tabel 9 terlihat bahwa ada perbedaan signifikan untuk aspek kinerja yaitu : virus - Sedangkan untuk aspek-aspek lainnya seperti tanggapan masalah, pemeliharaan $\mathrm{S} / \mathrm{W}, \mathrm{H} / \mathrm{W}$ dan Jaringan, pengembangan SI, pemeliharaan program \& SI dan password dan kontrol online tidak menunjukan perbedaan yang signifikan.

\section{Interpretasi Hasil Penelitian}

Hasil analisis yang telah dipaparkan sebelumnya menunjukan bahwa kinerja divisi TI, yang ditinjau dan kualitas produk dan layanan SI/TI berpengaruh secara positif terhadap kepuasan pelanggan internal dengan nilai signifikansi $+0,00$ yang berarti bahwa semakin tinggi kualitas produk dan layanan SI/TI maka semakin tinggi pula kepuasan pelanggan internal terhadap produk dan layanan SI/TI yang diberikan oleh divisi TI. Pelanggan internal merasa bahwa pelayanan yang mereka terima dari divisi TI saat ini adalah cukup baik.

Menurut pelanggan internal kebutuhan mereka akan SI/TI yang meliputi ketersediaan $\mathrm{H} / \mathrm{W}$ dan $\mathrm{S} / \mathrm{W}$ serta dukungan terhadap penggunaanya (yang diwakili oleh variabel : Availability, User Friendliness, Productivity, Reliability ,Durability, Responsiveness, Timeless Of Support telah dipenuhi dengan cukup baik oleh divisi TI dengan nilai untuk masingmasing variabel kualitas produk dan layanan SI/TI berada pada range nilai rata- rata antara $3.7-4.8$ (untuk lebih jelasnya dapat dilihat pada tabel 3). Secara keseluruhan pelanggan internal menilai bahwa kualitas produk dan layanan SI/TI yang dihasilkan oleh divisi TI saat ini cukup baik dengan nilai rata-rata untuk keseluruhan variabel independent (variabel kualitas produk dan layanan SI/TI) adalah sebesar 4.01 ( table 3 ) dan pelanggan internal merasa cukup puas (dengan nilai rata-rata $=3.97$ tabel 4 ) terhadap kinerja divisi TI saat ini, yang ditinjau dan kualitas produk dan layanan SI/TI.

Hasil analisis menunjukan hubungan yang kuat antara seluruh vaniabel kualitas produk dan layanan SI/TI terhadap kepuasan pelanggan, sehingga dapat disimpulkan bahwa kinerja divisi TI berpengaruh secara positif terhadap kepuasan pelanggan internal (menolak $\mathbf{H}_{0}$ pada hipotesis 1 untuk pengujian korelasi).

Seluruh variabel kualitas produk dan layanan SI/TI yang diuji pada penelitian ini mempunyai pengaruh yang signifikan dengan korelasi yang cukup kuat terhadap persepsi peningkatan kinerja pelanggan internal. Menurut Mathis dan Jackson [1] salah satu faktor yang mempengaruhi kinerja seseorang adalah kondisi perlengkapan kerja yang baik dalam hal ini adalah ketersediaan $\mathrm{H} / \mathrm{W}$ dan $\mathrm{S} / \mathrm{W}$ (yang diwakili oleh variabel availability, durability, productivity), dukungan pengguna juga berpengaruh terhadap persepsi peningkatan kinerja pelanggan internal (yang diwakili oleh variabel responsivenees dan timeless of support).

Ahli desain user-interface, wilbert galitz mengemukakan bahwa user-interfase dari suatu aplikasi yang tidak user-friendly akan menyebabkan penyalahgunaan, kepanikan, frustasi, kebosanan dan penurunan kinerja. Sehingga galitz menekankan pada human faktor atau melibatkan pengguna pada desain userinterface, dengan cara menemukan apa 
yang disukai dan tidak disukai oleh pengguna pada aplikasi mereka, sehingga kinerja pengguna benar-benar optimal [2].

Setelah menggunakan produk dan layanan SI/TI dari divisi TI, pelanggan internal merasa kinerja mereka meningkat cukup baik dengan nilai persepsi peningkatan kinerja keseluruhan adalah sebesar 3,95 ( tabel 4 ). Hasil penelitian menunjukan hubungan yang positif antara kinerja divisi TI yang ditinjau dan kualitas produk dan layanan SI/TI terhadap persepsi peningkatan kinerja pelanggan internal atau dengan kata lain hasil pengujian ini (menolak $\mathrm{H}_{0}$ pada hipotesis 2 untuk pengujian korelasi).

Hasil analisis Mann-Whitney menolak Ho dan menerima $\mathrm{H} 1$ pada hipotesis 3, artinya terdapat perbedaan penilaian aspek kinerja yang signifikan antara pelanggan internal dengan personel TI terhadap kinerja divisi TI. Adapun aspek-aspek kinerja yang memiliki perbedaan yang signifikan yaitu adalah : password (lihat tabel 8). Para pelanggan internal merasa bahwa saat ini tanggapan terhadap masalah password yang dilaporkan oleh bagian-bagian kerja yang ada di PGSN meski tidak buruk namun belum dilakukan secara baik oleh divisi TI. Sedangkan menurut personel TI, mereka sudah melakukan ketiga aspek kinerja tersebut dengan baik.

Sepintas, kesenjangan penilaian ini bukan masalah yang besar dan masih dapat ditoleransi, namun bila dibiarkan terus menerus bukan tidak mungkin suatu saat dimasa mendatang kesenjangan ini akan menjadi semakin lebar, yang akhirnya akan berdampak pada penurunan kinerja dari divisi TI. Untuk mengantisipasi kemungkinan yang lebih buruk dimasa mendatang diperlukan suatu upaya pencegahan.

Parasuraman telah merumuskan suatu model dasar kesenjangan yang dapat terjadi dalam layanan TI (IT service delivery) [3] yang dapat dilihat pada gambar berikut:

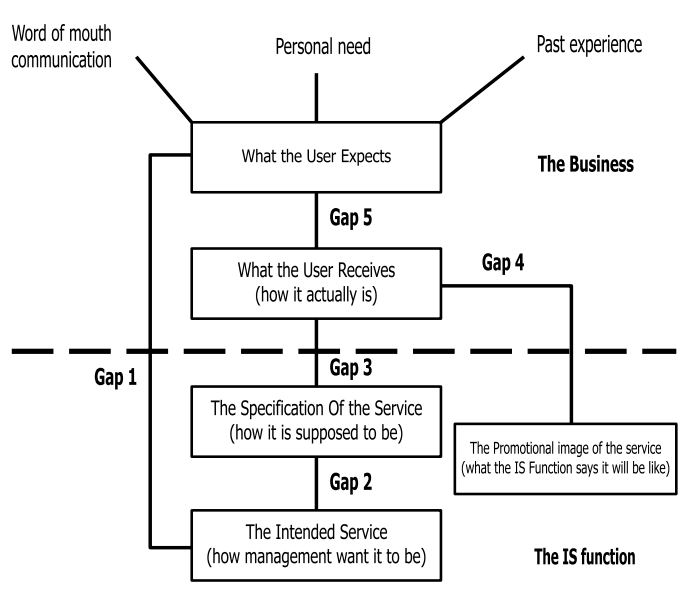

\section{Gambar 7. Kesenjangan Dalam IS} Service [3]

Berdasarkan hasil wawancara dan observasi langsung di lapangan, penulis menyimpulkan bahwa telah terjadi kesenjangan 4 dan kesenjangan 5 antara divisi TI dengan pelanggan internal yang disebabkan oleh :

- Komunikasi yang sudah terbina masih kurang konsisten dalam menjelaskan kepada komunitas pelanggan internal mengenai layanan SI yang dapat dilakukan oleh divisi TI.

- Kurangnya informasi yang diperoleh dari analisa atas kebutuhan pelanggan internal.

- Harapan pelanggan internal yang terlalu tinggi terhadap kinerja divisi TI, sehingga sulit untuk penuhi.

Untuk mengatasi masalah-masalah tersebut diatas maka dapat dilakukan hal-hal sebagai berikut :

Divisi TI sebaiknya menyusun suatu service level yang menuangkan batasan batasan layanan yang dapat dipenuhi oleh divisi TI, misalnya dalam hal tanggapan terhadap pengaduan kerusakan SI yang dilaporkan oleh divisi TI, perlu ditetapkan waktu maksimal kerusakan SI/TI tersebut 
dapat ditoleransi. Dan hal ini perlu disosialisasikan kepada pelanggan internal dan personel TI.

Divisi TI juga dapat menyusun suatu standar kinerja yang mengikuti model SMART, yaitu : Spesifik artinya standar dan tujuan kinerja harus menunjukan apa yang harus diselesaikan secara spesifik, measurable (dapat diukur), attainable (dapat dicapai), realistis dan time sensitive (peka dengan waktu), penyusunan TI scorecard untuk divisi TI merupakan solusi yang tepat. Sebagai contoh; dalam proses pengembangan SI perlu ditetapkan ukuran waktu pengembangan, tingkat kemudahan dan user manual aplikasi, jumlah kesalahan per aplikasi dan hal-hal lainnya secara jelas.

\section{SIMPULAN}

Berdasarkan hasil analisis yang telah diuraikan sebelumnya dapat disimpulkan :

1. Hasil analisis terhadap tujuh variabel independent kualitas produk dan layanan SI/TI yang diuji dalam penelitian menunjukan bahwa ada korelasi yang positif dan sangat kuat antara kinerja divisi TI terhadap kepuasan menyeluruh pelanggan internal.

2. Ketujuh variabel kualitas produk dan layanan SI/TI tersebut juga mempunyai pengaruh yang signifikan dengan korelasi yang cukup kuat terhadap persepsi peningkatan kinerja pelanggan internal.

Berdasarkan kesimpulan yang diperoleh dapat disarankan beberapa hal yaitu :

\section{Untuk Devisi SI / TI PT.PGSN}

Mengingat bahwa telah terjadi kesenjangan penilaian kinerja antara personel TI dengan pelanggan internal, untuk menghindari kesenjangan yang suatu saat dapat menjadi lebih lebar dimasa mendatang maka divisi TI di PGSN sebaiknya menyusun suatu service level yang menuangkan batasan- batasan service yang dapat dipenuhi oleh divisi TI bagi bagian-bagian kerja lain yang ada di PT.PGSN.

Dengan adanya suatu standar kinerja maka kontribusi pelayanan Sistem Informasi untuk organisasi perusahaan dapat diukur.

\section{Untuk penelitian Lanjutan}

Untuk penelitian selanjutnya dapat dikembangkan variabel independent kualitas produk dan layanan SI/TI yang lebih spesifik seperti kecepatan waktu tanggap aplikasi atau sistem informasi, kelengkapan content dan kelengkapan feature dari web dan lain-lain.

Untuk variabel dependent peningkatan kinerja pelanggan internal penilaian daat dikembangkan dengan menggunakan datadata nyata yang menunjukan peningkatan kinerja pelanggan internal setelah menggunakan produk SI/TI dibandingkan dengan kinerja sebelum menggunakan SI/TI. Jadi tidak bukan hanya persepsi pelanggan internal saja yang dinilai tapi juga hasil nyata dari peningkatan kinerja mereka.

\section{DAFTAR PUSTAKA}

[1] Mathis, R.L dan Jackson, J., Manajemen Sumber Daya Manusia. Jakarta: Salemba empat. 2008.

[2] Grembergen, Wim Van, et.al, Linking The IT Balanced Scorecard and IT Governance to the Business Objectives at a Major Canadian Financial Group. University of Antwerp. 2008.

[3] Ward, J., dan Peppard, J., Strategic Planning for Information System. $\left(3^{\text {rd }}\right.$ ed.). Chiester: John Wiley \& Son. 2004. 